\title{
Pengembangan Panduan Layanan Konseling Kelompok Berbasis Petualangan Untuk Meningkatkan Resiliensi Siswa SMP
}

\author{
(Development of an Adventure-Based Group Counseling Service Guide to Improve \\ Middle School Students' Resilience)
}

Handika Mulya Nurdestama*, Elia Flurentin, M. Ramli

Universitas Negeri Malang, Jl. Semarang No. 5 Malang, Jawa Timur, Indonesia

*Penulis korespondensi, Surel handikamulyan@gmail.com

Paper received: 11-Jan-2022; revised: 1-Feb-2022; accepted: 8-Feb-2022

\begin{abstract}
The research aims to develop an adventure-based group counseling service guide to improve student resilience. Adventure-based group counseling services are packaged in a guide that contains daily activities by reflecting on the actual situation and includes treatments to increase resilience. The researcher uses the Research and Development design developed by Borg and Gall with research steps: (1) data collection, (2) planning, (3) product development, (4) expert testing, (5) product design revision, (6) stage test potential users, (7) revise the product into a prototype. Researchers did not conduct field tests due to the Covid-19 pandemic. In the expert test, the product is tested by two experts in terms of material and media and then tested by potential users. The results of the expert and prospective user test assessments show that the guide in the form of a prototype has met the acceptance criteria, so it is feasible to use.
\end{abstract}

Keywords: adventure-based counseling; resilience; junior high school students

\begin{abstract}
Abstrak
Penelitian bertujuan mengembangkan panduan layanan konseling kelompok berbasis petualangan untuk meningkatkan resiliensi siswa. Layanan konseling kelompok berbasis petualangan dikemas dalam suatu panduan yang memuat aktivitas keseharian dengan merefleksikan situasi sebenarnya, serta memuat treatment untuk meningkatkan resiliensi. Peneliti menggunakan desain Research and Development yang dikembangkan oleh Borg dan Gall dengan langkah penelitian: (1) pengumpulan data, (2) perencanaan, (3) pengembangan produk, (4) uji ahli, (5) revisi desain produk, (6) tahap uji calon pengguna, (7) revisi produk menjadi prototipe. Peneliti tidak melakukan uji lapangan karena adanya pandemi Covid-19. Pada uji ahli produk diuji oleh 2 ahli dari segi materi dan media dan selanjutnya diuji oleh calon pengguna. Hasil penilaian uji ahli dan calon pengguna menunjukkan bahwa panduan berupa prototipe telah memenuhi kriteria keberterimaan, sehingga layak untuk digunakan.
\end{abstract}

Kata kunci: konseling berbasis petualangan; resiliensi; siswa SMP

\section{Pendahuluan}

Secara alami psikologis remaja sangat rentan dalam menghadapi berbagai tekanan, karena di usia remaja merupakan masa perkembangan psikologis dari anak-anak ke dewasa (Batubara, 2016). Bahkan dewasa ini tidak ada seorang anak pun yang terbebas dari tekanan, perubahan yang terjadi secara cepat dan lingkungan yang memberi pengaruh stres telah menciptakan resiko baru bagi anak-anak dan remaja (Goldstein \& Brooks, 2013). 
Masalah yang dijumpai dan dialami oleh remaja sangat beraneka ragam. Hasil wawancara dengan konselor dan hasil observasi di SMP Islam Ma'arif 02 Kota Malang, menunjukkan bahwa sebagian besar siswa dari kalangan menengah ke bawah dan hampir 50\%, banyak dari mereka berasal dari keluarga broken, ditinggal orangtua bekerja di luar negeri, dititipkan ke neneknya sehingga hidup sendiri jauh dari orangtua dan juga pernah mengalami bullying. Berdasarkan sumber masalah tersebut konselor menyampaikan, bahwa pengaruh yang dibawa dari permasalahan tersebut berupa penurunan tingkat ketahanan siswa. Kegagalan siswa dalam mengembangkan dan mengontrol emosi membuat siswa kurang mampu menghadapi sumber tekanan yang menimpanya. Ditengah peristiwa negatif resiliensi menjadi salah satu kemampuan yang penting dimiliki remaja.

Resiliensi merupakan kompetensi dasar yang harus dimiliki di abad ke-21 ini (Hendriani, 2018). Resiliensi merupakan kapasitas yang bersifat universal dan dengan kapasitas tersebut, individu, kelompok ataupun komunitas mampu mencegah, meminimalisir ataupun melawan pengaruh yang bisa merusak saat individu mengalami musibah atau kemalangan (Grotberg, 1995). Resiliensi memiliki beberapa faktor pendukung seperti percaya pada lingkungan, otonomi diri, inisiatif menjalin interaksi, industri, dan pemahaman identitas (Hendriani, 2018).

Resiliensi siswa perlu dikembangkan dengan layanan yang sesuai dan juga yang menarik. Salah satu penelitian terdahulu tentang resiliensi, menunjukkan bahwa resiliensi yang dikembangkan dengan konseling tradisional beresiko ditolak konseli (Setyowati, Suardiman, \& Fauziah, 2019). Hal ini juga didukung oleh Fletcher dan Hinkle (2002) yang menyebutkan bahwa konseling tradisional yang terbatas kurang memberikan dampak perubahan pada individu dari pada pengalaman di luar ruangan. Layanan konseling memiliki beragam teknik untuk meningkatkan resiliensi (Diana, 2021; Fitri \& Kushendar, 2019; Mashudi, 2016). Dari beragam teknik yang pernah digunakan, peneliti memilih teknik konseling berbasis petualangan yang lebih berfokus pada suasana belajar dari pengalaman untuk meningkatkan resiliensi.

Konseling kelompok berbasis petualangan merupakan kombinasi belajar eksperiensial (experiential learning) dengan belajar di luar ruangan (outdoor education) yang menggunakan teknik-teknik konseling kelompok (Fletcher \& Hinkle, 2002). Konseling berbasis petualangan merupakan model konseling yang dapat disesuaikan melalui banyak pengaturan dan sengaja memanfaatkan kegiatan petualangan untuk memfasilitasi pertumbuhan sosio-emosional dan pribadi serta perilaku perubahan konseli (Fletcher \& Hinkle, 2002). Tantangan fisik dalam suatu petualangan memungkinkan konseli untuk dapat mengekspresikan rasa frustasi dan kecemasan, sehingga dapat mengurangi stress (Setyowati et al., 2019). Melalui layanan responsif dengan konseling kelompok berbasis petualangan siswa akan mendapatkan manfaat dalam mengembangkan bagaimana cara berinteraksi dengan teman lain dan menyelesaikan masalah dari hasil belajar pengalaman selama konseling kelompok berlangsung.

Berdasarkan kajian di atas, menunjukkan bahwa layanan konseling kelompok berbasis petualangan juga mampu untuk meningkatkan resiliensi namun masih belum ada penelitian pengembangan panduan layanan konseling kelompok berbasis petualangan untuk meningkatkan resiliensi. Penelitian ini bertujuan untuk mengembangkan panduan layanan konseling kelompok berbasis petualangan untuk meningkatkan resiliensi siswa SMP. Melalui pengembangan buku panduan ini peneliti membantu memberikan pemahaman tentang teknik 
konseling ini karena konseling berbasis petualangan termasuk masih baru dalam penerapan konseling di sekolah menengah pertama. Buku panduan ini, diharapkan dapat membantu konselor untuk merealisasikan layanan konseling berbasis petualangan secara sistematis dan terarah sesuai dengan langkah langkah dalam buku panduan.

\section{Metode}

Pada penelitian ini, penulis akan mengembangkan suatu produk buku panduan layanan konseling kelompok dengan konseling berbasis petualangan untuk meningkatkan resiliensi siswa SMP. Peneliti menggunakan desain Research and Development yang dikembangkan oleh Borg dan Gall dengan 10 langkah penelitian. Dalam realisasinya, peneliti menyesuaikan dengan kondisi sosial dan juga fenomena yang terjadi di tengah-tengah kondisi pendidikan saat pandemi.

Melihat kondisi pandemi Covid-19, peneliti hanya mengadaptasi 7 langkah yang sesuai dengan situasi lapangan. Tujuh langkah tersebut adalah: (1) Penelitian dan pengumpulan data melalui wawancara peneliti dengan konselor dan hasil observasi peneliti di sekolah menengah pertama. Selanjutnya peneliti melakukan studi literatur untuk mengkaji dan mendalami permasalahan yang muncul dari hasil asesmen awal yang telah dilakukan; (2) Perencanaan pembuatan produk panduan layanan konseling kelompok berbasis petualangan untuk meningkatkan resiliensi siswa SMP, dengan desain prototipe yang dibuat berdasarkan data dan informasi kebutuhan siswa SMP serta kebutuhan konselor di sekolah; (3) Pengembangan draf produk dengan susunan kasar untuk menjadi produk awal. Penyusunan draf produk dalam penelitian pengembangan disusun dengan selengkap mungkin untuk selanjutnya diujikan pada pakar-pakar; (4) Uji ahli untuk mengetahui tingkat penilaian akseptabilitas dan keefektifan produk dalam meningkatkan resiliensi, peneliti juga melakukan pengujian oleh penguji ahli materi dan media. Ahli yang menguji produk berasal dari dosen Bimbingan dan Konseling serta Teknologi Pendidikan dengan jenjang pendidikan minimal S2; (5) Revisi produk uji ahli berdasarkan hasil penilaian, kritik perbaikan serta saran dalam proses memperbaiki kekurangan dari produk buku panduan; (6) Uji calon pengguna, peneliti menggunakan subjek uji calon pengguna adalah guru BK SMP. Hasil perbaikan dan revisi dari uji ahli materi dan media diberikan kepada guru BK untuk melakukan penilaian terhadap produk melalui instrumen yang sudah disusun oleh peneliti untuk mengetahui kelayakan produk; (7) Penilaian produk oleh calon pengguna, untuk melihat keberterimaan produk buku panduan dengan kisi-kisi instrumen. Kisi-kisi instrumen yang disusun meliputi 5 aspek, yakni: ketepatan, kegunaan, kemudahan, kepatuhan dan kemenarikan. Penilaian dilakukan setelah calon pengguna menggunakan produk yang disusun oleh peneliti. Hasil penilaian ini nantinya sebagai acuan untuk memperbaiki dan juga meningkatkan keberterimaan produk dengan kelima unsur tersebut.

Hasil pengujian berupa data kuantitatif yang didapatkan dari instrumen uji ahli dan uji calon pengguna yang sudah dibuat dan dilakukan sebelumnya. Data kuantitatif didapatkan dari hasil instrumen penilaian dalam bentuk angka dan dianalisis dengan teknik persentase. Data kuantitatif yang dihasilkan dari hasil penjumlahan keseluruhan tiap data diproses dengan cara dijumlah kemudian dijumlah dengan jumlah yang diharapkan sehingga dapat diperolehnya hasil persentase keberterimaan (Arikunto, 2013). Rumus yang digunakan sebagai berikut:

Persentase keberterimaan $\%=\frac{\text { skor yang diobservasi }}{\text { skor yang diharapkan }} \times 100 \%$ 
Pencarian persentase dimaksudkan untuk mengetahui status hasil yang diharapkan sehingga dapat mengetahui status keberterimaan produk. Kriteria keberterimaan produk disajikan pada tabel 1 .

Tabel 1. Kriteria Keberterimaan Produk

\begin{tabular}{ccc}
\hline Persentase pencapaian & Kategori/Interpretasi & Kualifikasi \\
\hline $76-100 \%$ & Sangat Layak & Sangat Valid / Tidak Revisi \\
$56-75 \%$ & Layak & Valid / Revisi Sebagian \\
$40-55 \%$ & Cukup & Kurang Valid/ Revisi Sebagian \\
$0-39 \%$ & Kurang Layak & Tidak Valid / Revisi Keseluruhan \\
\hline
\end{tabular}

Tabel skala tersebut digunakan untuk menentukan keberterimaan suatu produk yang dihasilkan. Skala persentase 1 dengan persentase pencapaian 0-39\% mendapatkan interpretasi kurang keberterimaan dan kualifikasi tidak valid maka dilakukan revisi secara keseluruhan. Skala 2 dengan persentase pencapaian 40-75\% mendapatkan interpretasi cukup keberterimaan dan kualifikasi kurang valid maka dilakukan revisi sebagian. Skala nilai 3 dengan persentase pencapaian 56-75\% mendapatkan interpretasi keberterimaan dan kualifikasi valid maka dilakukan revisi sebagian. Skala nilai 4 dengan persentase pencapaian 76-100\% mendapatkan interpretasi sangat keberterimaan dan kualifikasi sangat valid maka tidak dilakukan revisi. Nilai keberterimaan untuk produk panduan layanan konseling kelompok berbasis petualangan untuk meningkatkan resiliensi siswa SMP memiliki kriteria keberterimaan minimal cukup untuk diserahkan kepada pihak yang berwenang.

\section{Hasil dan Pembahasan}

\subsection{Hasil}

Hasil pengumpulan data yang dilakukan melalui wawancara peneliti dengan konselor dan hasil observasi peneliti di sekolah menengah pertama. Hasil menunjukkan sebagian besar siswa dari kalangan menengah kebawah dan hampir 50\% dari mereka dari keluarga broken, ditinggal orangtua kerja di luar negeri, dititipkan ke neneknya, dan bahkan hidup sendiri jauh dari orangtua. Kelompok remaja ini memiliki tekanan dalam tahap perkembangannya. Berdasarkan paparan tersebut siswa SMP yang memiliki tingkat resiliensi rendah perlu mendapatkan layanan konseling kelompok dengan menggunakan konseling berbasis petualangan. Setelah dilakukan pengkajian peneliti melakukan perencanaan dalam membuat media panduan layanan konseling kelompok berbasis petualangan untuk meningkatkan resiliensi siswa SMP. Buku panduan tersebut ditujukan kepada konselor di sekolah sebagai penggunanya.

Dalam proses pengembangan draf produk, peneliti mendesain sampul dari panduan dengan warna utama ungu. Pada bagian atas dicantumkan judul dan juga logo Universitas Negeri Malang sebagai lembaga yang menaungi pembuatan buku panduan. Di bagian bawah disertakan identitas penulis dan asal lembaga. Peneliti menyertakan gambar yang mengilustrasikan kegiatan petualangan dengan beberapa simbol gambar seperti arah panah menghadap ke atas, teks box, gir, bendera, dan busur panah beserta sasaran.

Komponen dalam panduan ini terdiri dari penjabaran tentang rasional dan urgensi atas dipilihnya layanan konseling berbasis petualangan, tujuan umum dirancangnya panduan, dan 
sasaran pengguna panduan. Pada bagian selanjutnya dijelaskan pengertian layanan konseling berbasis petualangan. Teknis pelaksanaan, diperjelas dengan petunjuk pelaksanaan secara umum dan khusus, prosedur pelaksanaan layanan serta pada bagian terakhir terdapat evaluasi proses dan hasil untuk mengetahui tingkat keberhasilan penerapan layanan yang telah diberikan.

Panduan yang dikembangkan juga melalui proses pengujian untuk menentukan keberterimaan produk untuk digunakan konselor sekolah. Pengujian dilakukan oleh ahli materi dan media, lalu selanjutnya diuji cobakan kepada calon pengguna. Hasil dari pengujian berupa data kuantitatif antara lain sebagai berikut:

Hasil penilaian ahli materi menunjukkan total rata-rata persentase $100 \%$ dengan kategori sangat layak. Analisis penilaian ahli materi secara keseluruhan menunjukkan bahwa buku panduan layanan konseling kelompok berbasis petualangan untuk meningkatkan resiliensi siswa SMP merupakan produk panduan yang sangat berterima, tepat dan jelas untuk digunakan oleh konselor sekolah.

Hasil penilaian ahli media menunjukkan total rata-rata persentase $97 \%$ dengan kategori sangat layak. Analisis penilaian ahli materi secara keseluruhan menunjukkan bahwa buku panduan layanan konseling kelompok berbasis petualangan untuk meningkatkan resiliensi siswa SMP dinilai sebagai produk panduan yang berterima sesuai dengan penilaian penguji ahli media. Terdapat beberapa saran umum untuk ditambahkan pada panduan yaitu, penamaan bagian sampul, penggunaan format font yang harus disesuaikan kembali dan desain footer bagian tulisan yang perlu diperkecil dan diganti warna hitam.

Hasil penilaian uji coba calon pengguna menunjukkan total rata-rata persentase yaitu 94,5 \% dengan kategori sangat layak. Analisis penilaian calon pengguna menunjukkan bahwa buku panduan layanan konseling kelompok berbasis petualangan untuk meningkatkan resiliensi siswa SMP merupakan produk panduan yang dapat diterima, namun masih ada beberapa hal yang perlu ditambahkan. Pada bagian ilustrasi gambar dan perpaduan warna sedikit kurang bervariasi, materi dan isi dinilai sangat menarik namun perlu ditambahkan gambar langkah-langkah dalam permainan yang sedang dimainkan seorang anak.

Proses penilaian ini nantinya digunakan sebagai acuan untuk memperbaiki dan juga meningkatkan keberterimaan produk dengan kelima unsur tersebut. Setelah dilaksanakan uji calon pengguna oleh guru BK SMP, peneliti melakukan perbaikan sesuai dengan penilaian, saran, masukan dan kritik dari calon pengguna. Revisi produk dari calon pengguna ini bertujuan untuk menyempurnakan produk peneliti berupa buku panduan layanan konseling kelompok dengan konseling berbasis petualangan agar produk lebih layak digunakan oleh guru BK untuk memfasilitasi siswa dalam layanan bimbingan dan konseling agar dapat meningkatkan resiliensi pada siswa SMP. Produk akhir akan dihasilkan setelah melakukan revisi dan akan diberikan kepada konselor berupa buku panduan berjudul "Panduan Layanan Konseling Kelompok dengan Konseling Berbasis Petualangan untuk meningkatkan Resiliensi Siswa SMP Islam Ma'arif 02 Kota Malang". 


\subsection{Pembahasan}

Secara alami psikologis remaja sangat rentan untuk menghadapi tekanan-tekanan, karena di usia remaja merupakan masa perkembangan psikologis dari anak-anak ke dewasa (Batubara, 2016). Hasil wawancara dengan konselor dan observasi di SMP Islam Ma'arif 02 Kota Malang, menunjukkan bahwa sebagian besar siswa dari kalangan menengah ke bawah dan hampir 50\%, banyak dari mereka berasal dari keluarga broken, ditinggal orangtua bekerja di luar negeri, dititipkan ke neneknya sehingga hidup sendiri jauh dari orangtua dan juga pernah mengalami bullying. Di tengah peristiwa negative, resiliensi menjadi salah satu kemampuan yang penting dimiliki remaja. Hal ini dikarenakan resiliensi merupakan kompetensi dasar yang harus dimiliki di abad ke-21 ini (Hendriani, 2018). Dalam penelitian terdahulu untuk meningkatkan resiliensi beragam teknik konseling telah dilakukan (Diana, 2021; Pardede \& Dalimunthe, 2020). Namun begitu, perlu dilakukan penelitian lanjutan dan pengembangan panduan $S F B C$ dalam konseling kelompok yang memenuhi keberterimaan baik secara teoritik maupun secara praktik.

Pada dasarnya, konseling berbasis petualangan merupakan suatu kombinasi antara belajar eksperiensial (experiential learning) dengan belajar di luar ruangan (outdoor education) yang menggunakan teknik-teknik konseling kelompok (Fletcher \& Hinkle, 2002). Urgensi dalam pembuatan panduan ini juga bersumber dari kebutuhan konselor akan panduan yang memuat teknik dan tahapan dari konseling berbasis petualangan. Guru BK merasa konseling yang dilaksanakan selama ini masih tergolong monoton dengan teknik yang terbilang mainstream. Melihat pentingnya layanan ini, peneliti memfokuskan untuk membuat panduan dengan tujuan mempermudah guru BK dalam menjalankan layanan konseling kelompok berbasis petualangan.

Peneliti mengembangkan buku paduan yang berjudul "Pengembangan Panduan Layanan Konseling Kelompok Berbasis Petualangan untuk Meningkatkan Resiliensi pada Siswa SMP". Tujuan secara umum dari buku panduan ini adalah untuk membantu guru BK dalam memberikan layanan konseling kelompok dengan konseling berbasis petualangan untuk meningkatkan kemampuan resiliensi siswa SMP. Buku dan karya tulis lainnya sebagai pranata ilmu, teknologi, dan seni, serta norma-norma peradaban merupakan sarana yang efektif bagi peningkatan dan pengembangan ilmu, keterampilan, penerapan teknologi, dan budaya bangsa (Humairo, Nursalim, Pratiwi, \& Nuryono, 2013). Panduan ini, diharapkan dapat membantu guru BK untuk merealisasikan layanan konseling berbasis petualangan secara sistematis dan terarah sesuai dengan langkah-langkah dalam panduan.

Komponen dalam panduan ini terdiri dari penjabaran tentang rasional dan urgensi atas dipilihnya layanan konseling berbasis petualangan, tujuan umum dirancangnya panduan, dan sasaran pengguna panduan. Agar mudah digunakan, panduan harus berisi petunjuk singkat dan lengkap (Wellhausen \& Fiesser, 2011). Teknis pelaksanaan juga diperjelas dengan petunjuk pelaksanaan secara umum dan khusus, prosedur pelaksanaan layanan serta pada bagian terakhir terdapat evaluasi proses dan hasil untuk mengetahui tingkat keberhasilan penerapan layanan yang telah diberikan. Pengembangan panduan konseling kelompok berbasis petualangan dalam penggunaannya ditujukan kepada guru BK yang akan memberikan layanan untuk meningkatkan resiliensi siswa. Panduan layanan konseling kelompok berbasis petualangan untuk meningkatkan resiliensi secara praktik dijalankan oleh guru BK dengan sasaran layanan yaitu siswa sekolah menengah pertama. 
Prosedur penggunaan buku panduan ini, digunakan sebagai rujukan dengan konselor membaca panduan ini. Guru BK sebagai pemimpin kelompok akan memberikan pembukaan dengan menjelaskan teknik yang akan digunakan untuk meningkatkan resiliensi siswa. Guru BK menjelaskan kepada siswa pentingnya resiliensi di tengah problematika yang sedang terjadi. Pada tahapan kerja, guru BK dapat melihat alternatif permainan beserta tata cara, aturan serta manfaat dari permainan petualangan tersebut dalam panduan. Pada tahap terminasi konselor bisa melakukan evaluasi baik proses dan hasil, sesuai dengan inventori dalam panduan. Evaluasi keberhasilan yang dilakukan dengan berdasarkan proses pelaksanaan layanan konseling kelompok dengan konseling berbasis petualangan dan juga hasil dari proses pelaksanaan layanan.

Dalam melihat keberterimaan produk peneliti melakukan pengujian dari segi materi dan media serta pengujian dari pihak pengguna. Pengujian dilakukan untuk menilai keberterimaan produk yang telah disusun sebelumnya. Aspek yang diamati seperti ketepatan, kegunaan, kemudahan, dan kemenarikan. Hasil pengujian berupa data kuantitatif yang didapatkan dari instrumen uji ahli dan uji calon pengguna yang sudah dibuat dan dilakukan sebelumnya. Data kuantitatif yang dihasilkan dari hasil penjumlahan keseluruhan tiap data diproses dengan cara dijumlah kemudian dijumlah dengan jumlah yang diharapkan sehingga dapat diperolehnya hasil persentase keberterimaan (Arikunto, 2013).

Pada uji keberterimaan isi materi dilakukan oleh dosen Bimbingan Konseling. Hasil yang diperoleh dari penilaian secara kuantitatif ditunjukan dalam persentase yang disertai deskripsi tentang produk yang dinilai. Analisis data angka menunjukkan persentase kelayakan sebesar $100 \%$, dan termasuk kategori sangat layak. Ice breaking ada kegiatan yang berguna untuk proses belajar mengajar (Yeganehpour, 2017). Pada bagian saran terdapat anjuran menambahkan ilustrasi gambar pada bagian ice breaking agar calon pengguna dapat memahami langkah ice breaking tersebut.

Selanjutnya hasil penilaian keberterimaan produk sebagai media bimbingan dan konseling dinilai oleh satu penguji media dari dosen Teknologi Pendidikan. Hasil penilaian ahli media menunjukkan total rata-rata persentase yaitu 97\% dengan kategori sangat layak. Analisis penilaian ahli materi secara keseluruhan dapat diketahui bahwa buku panduan layanan konseling kelompok berbasis petualangan untuk meningkatkan resiliensi siswa SMP dinilai sebagai produk panduan yang berterima sesuai dengan penilaian penguji ahli media. Terdapat beberapa saran umum untuk ditambahkan pada panduan yaitu, penamaan bagian sampul, penggunaan format font yang harus disesuaikan kembali dan design footer bagian tulisan yang perlu diperkecil dan diganti warna hitam. Tampilan produk yang menarik dapat membuat orang tertarik (Tiwasing, Sahachaisaeree, \& Hapeshi, 2014).

Hasil penilaian uji coba calon pengguna menunjukkan total rata-rata persentase yaitu 94,5 dengan kategori sangat layak. Analisis penilaian calon pengguna menunjukkan bahwa buku panduan layanan konseling kelompok berbasis petualangan untuk meningkatkan resiliensi siswa SMP merupakan produk panduan yang berterimaan, namun masih ada beberapa hal yang perlu ditambahkan. Pada bagian ilustrasi gambar dan dan perpaduan warna sedikit kurang bervariasi, materi dan isi dinilai sangat menarik namun perlu ditambahkan gambar langkah-langkah dalam permainan yang sedang dimainkan seorang anak.

Pramo, Bistamam, dan Arip, (2017) juga melakukan penelitian berkaitan dengan pengaruh konseling berbasis petualangan pada ketahanan di antara peserta pelatihan 
nasional, fokus penelitian dari penelitian ini menjadi perbandingan yang terletak pada fokus penelitian, penelitian ini fokus pada pengembangan panduan yang bertujuan membuat media untuk membantu konselor dalam melaksanakan layanan konseling kelompok bidang pribadisosial untuk membantu siswa dalam meningkatkan resiliensi guna tercapainya SKKPD kematangan emosional dan intelektual. Kekurangan dari penelitian ini adalah produk yang dikembangkan tidak sampai diujicobakan secara langsung kepada siswa untuk dapat mengukur keefektifan produk karena situasi pandemi Covid-19.

\section{Simpulan}

Penelitian yang dilakukan merupakan upaya pengembangan panduan layanan konseling kelompok berbasis petualangan untuk meningkatkan resiliensi siswa SMP. Fokus pengembangan panduan yaitu sebagai media untuk membantu konselor dalam melaksanakan layanan konseling kelompok bidang pribadi-sosial untuk membantu siswa dalam meningkatkan resiliensi guna tercapainya SKKPD kematangan emosional dan intelektual. Berdasarkan hasil analisis produk panduan telah mencapai keberterimaan dan sangat layak digunakan karena sesuai dengan unsur ketepatan, kegunaan, kemenarikan, dan kemudahan. Dalam langkah-langkah penelitian masih terdapat kekurangan yakni tidak melakukan uji langsung kepada siswa, oleh karena itu saran untuk peneliti selanjutnya agar melanjutkan penelitian dilangkah yang lebih lengkap dengan menguji keefektifan produk buku panduan kepada siswa SMP secara langsung.

\section{Daftar Rujukan}

Arikunto, S. (2013). Prosedur Penelitian; Suatu Pendekatan Praktik. Jakarta: PT. Rineka Cipta.

Batubara, J. R. L. (2016). Adolescent Development (Perkembangan Remaja). Sari Pediatri, 12(1), 21-29.

Diana, L. W. (2021). Efektivitas Konseling Kelompok Pendekatan Solution-Focused Brief Counseling (Sfbc) Untuk Meningkatkan Resiliensi Siswa Smp Islam Al Amal Surabaya. HELPER: Jurnal Bimbingan Dan Konseling, 38(1), 26-34.

Fitri, H. U., \& Kushendar, K. (2019). Konseling Kelompok Cognitive Restructuring untuk Meningkatkan Resiliensi Akademik Mahasiswa. Bulletin of Counseling and Psychotherapy, 1(2), 67-74.

Fletcher, T. B., \& Hinkle, J. S. (2002). Adventure based counseling: An innovation in counseling. Journal of Counseling \& Development, 80(3), 277-285.

Goldstein, S., \& Brooks, R. B. (2013). Why study resilience? In Handbook of resilience in children (pp. 3-14). Springer.

Grotberg, E. H. (1995). A guide to promoting resilience in children: Strengthening the human spirit (Vol. 8). Bernard van leer foundation The Hague, Netherlands.

Hendriani, W. (2018). Resiliensi psikologis: sebuah pengantar. Kencana.

Humairo, D., Nursalim, M., Pratiwi, T. I., \& Nuryono, W. (2013). Pengembangan Buku Panduan Studi Lanjut untuk Siswa SMA Kelas XI. Jurnal BK Unesa, 3(1).

Mashudi, E. A. (2016). Konseling rational emotive behavior dengan teknik pencitraan untuk meningkatkan resiliensi mahasiswa berstatus sosial ekonomi lemah. Jurnal Psikopedagogia, 5(1), 66-78.

Pardede, N., \& Dalimunthe, S. N. (2020). Efektivitas Layanan Konseling Kelompok Dalam Meningkatkan Resiliensi Siswa SMP Muhammadiyah 29 Padangsidimpuan. Ristekdik: Jurnal Bimbingan Dan Konseling, 5(1), 7-13.

Pramo, W. P., Bistamam, M. N., \& Arip, M. A. S. M. (2017). Effect of Adventure Based Counselling on Resilience among National Service Trainee. International Journal of Academic Research in Business and Social Sciences, 7(9), 2222-6990.

Setyowati, A., Suardiman, S. P., \& Fauziah, M. (2019). Keefektifan Program Adventure Based Counseling untuk Meningkatkan Kebahagiaan Mahasiswa. Jurnal Kajian Bimbingan Dan Konseling, 4(2), 69-74. https://doi.org/10.17977/um001v4i22019p069 
Buletin Konseling Inovatif, 1(2), 2021, 74-82

Tiwasing, W., Sahachaisaeree, N., \& Hapeshi, K. (2014). Design goals and attention differentiations among target groups: A case of toy packaging design attracting children and parents' purchasing decision. Design Principles and Practices, 7(1), 29-43.

Wellhausen, T., \& Fiesser, A. (2011). How to write a pattern? Proceedings of the 16th European Conference on Pattern Languages of Programs - EuroPLoP '11, 1-9. New York, New York, USA: ACM Press. https://doi.org/10.1145/2396716.2396721

Yeganehpour, P. (2017). Ice-Breaking as a Useful Teaching Policy for Both Genders. Online Submission, 8(22), 137-142. 